\title{
Membangun Generasi Milenial yang Cinta Tanah Air Melalui Potensi Profesi dan Wirausaha
}

\author{
Fika Rahmanita ${ }^{\text {a.1 }}$, Jeni Andriani ${ }^{\text {b.2 }}$, Cornelia Dumarya Manik ${ }^{c .3}$ \\ ${ }^{a}$ Fakultas Keguruan dan Ilmu Pendidikan, Universitas Pamulang* \\ b, c Fakultas Ekonomi, Universitas Pamulang* \\ ${ }^{1}$ dosen01930@unpam.ac.id; ${ }^{2}$ dosen00436@unpam.ac.id; ${ }^{3}$ dosen00720@unpam.ac.id; \\ *Korespondensi Penulis
}

Naskah diterima: 20 Februari 2020; direvisi: 1 Maret 2020; disetujui: 12 Maret 2020

\begin{abstract}
Abstrak
Pulau Untung Jawa menjadi destinasi wisata memberikan peluang berwirausaha bagi warga sekitar. Oleh karena itu sebaiknya dilakukan sosialisasi mengenai nilai-nilai kewirausahaan dan cinta tanah air pada masyarakat sekitar Pulau Untung Jawa. Pengabdian ini bertujuan untuk membangun generasi milenial yang cinta tanah air melalui potensi profesi dan kewirausahaan. Metode pengabdian masyarakat ini berupa penyuluhan kepada 50 remaja di Pulau Untung Jawa. Hasil pengabdian ini menunjukkan adanya peningkatan pemahaman remaja tentang rasa cinta tanah air melalui potensi profesi dan wirausaha. Hal ini terlihat pada peningkatan hasil post-test yaitu 84,2 dibandingkan dari pre-test sebesar 74,6. Pengabdian masyarakat ini dilanjutkan dengan memberikan pelatihan pembuatan kerajinan tangan. Namun, dari 50 peserta kegiatan pelatihan, terdapat 47 peserta telah mengikuti pelatihan dengan baik. Sedangkan 3 peserta lainnya, masih belum menyelesaikan proses pembuatan sesuai dengan waktu yang ditentukan. Saran dari kegiatan ini, pengabdian lanjutan dapat dilakukan dengan memberikan pelatihan manajerial, marketing, dan pelaporan keuangan usaha yang dilakukan masyarakat.
\end{abstract}

Kata kunci: cinta tanah air, profesi dan kewirausahaan

\begin{abstract}
Untung Java Island becomes a tourist destination providing entrepreneurial opportunities for local residents. Therefore, it is better to do socialization about the values of entrepreneurship and love of homeland in the community around Pulau Untung java. This devotion aims to build a millennial generation who love homeland through the potential of profession and entrepreneurship. This method of community devotion in the form of socialization to 50 teenagers in Untung Java island. The results showed an increase in adolescents ' understanding of the love of homeland through professional and entrepreneurial potential. This is seen in the improved post-test result of 84.2 compared to the pre-test of 74.6. This community service was continued by providing training for handicraft making. However, from 50 participants, there are 47 participants who have been training well. While the other 3 participants, still have not completed the process of making according to the specified time. The advice of this activity, continued devotion can be done by providing managerial training, marketing, and financial reporting of the Community's efforts.
\end{abstract}

Keywords: patriotism, profession and entrepreneurship 


\section{PENDAHULUAN}

Kepulauan Seribu adalah salah satu tujuan wisata bahari warga Jakarta, Tangerang dan sekitarnya. Kepulauan seribu adalah pilihan destinasi wisata laut, alam dan sejarah. Gugusan kepulauan Seribu terdiri dari ratusan buah pulau. Pulau Untung Jawa adalah satu pulau di Kepulauan Seribu yang memberikan tawaran panorama pantai indah. Pulau Untung Jawa memiliki jarak tempuh yang cukup dekat dengan Ibukota, sehingga Pulau Untung Jawa dapat menjadi pilihan destinasi wisata laut yang dapat menjadi alternatif pelepas penat di tengah-tengah kesibukan kota Jakarta. Pulau Untung Jawa memberikan peluang berwirausaha bagi warga sekitar. Melihat potensi pasar yang cukup besar, sebaiknya dilakukan kegiatan yang dapat bermanfaat bagi peningkatan kreativitas warga masyarakat agar dapat memberikan kesempatan bagi masyarakat sekitar untuk mendapatkan penghasilan.

Profesi adalah pekerjaan yang dihasilkan dengan melalui proses pelatihan mengenai sebuah keahlian. Keahlian tersebut digunakan sebagai cara dalam menyelesaikan sebuah pekerjaan. Suatu profesi biasanya memiliki asosiasi profesi, kode etik, serta proses sertifikasi dan lisensi yang khusus untuk bidang profesi tersebut. Menurut Kusnandar (2007: 211), profesi adalah suatu kumpulan atau set pekerjaan yang membangun suatu set norma yang sangat khusus yang berasal dari perannya yang khusus di masyarakat.

$$
\text { Zimmerer (2008) menyampaikan }
$$
bahwa entrepreneurship (kewirausahaan) adalah bagaimana seseorang dapat berkreasi dan berinovasi dengan tujuan memecahkan masalah dan memanfaatkan peluang yang ada di depan mata pada kegiatan sehari-hari yang dilakukannya. Selanjutnya, Dubrin (2008) mengatakan bahwa entrepreneur adalah seseorang yang berperan untuk membentuk dan menjalankan sebuah usaha dengan daya inovasi. Sehingga kewirausahaan dapat disimpulkan bahwa seorang yang memiliki peran dalam membentuk dan menjalankan usaha dengan memanfaatkan kemampuan inovasi dan kreativitas dalam dirinya untuk mengelola usaha serta memecahkan masalah yang berkaitan dengan usahanya dan mampu membaca serta memanfaatkan peluang yang dihadapi masyarakat.

Peluang usaha muncul dari berbagai macam sumber inspirasi dalam membuat, menjalankan, dan mengembangkan usaha. Peluang bisnis memberikan kesempatan bagi seseorang dalam menjalankan membangun usaha. Usaha yang dibangun kemudian dikembangkan dengan menggunakan ide yang inovatif. Permasalahan yang muncul di depan akibat adanya usaha tersebut juga 
menuntut kreativitas pemilik usaha untuk dapat memenangkan persaingan.

Selain wisatawan lokal, Pulau Untung Jawa juga menjadi tujuan wisata bagi wisatawan mancanegara. Hal tersebut terbukti dengan beberapa kunjungan yang dilakukan oleh para turis mancanegara ke Pulau Untung Jawa. Adanya kunjungan dari wisatawan domestik dan mancanegara dapat berdampak kepada globalisasi yang ditularkan pada masyarakat lokal.

Beberapa dampak negatif yang dapat muncul antara lain pornografi, dan meningkatnya teknologi yang digunakan. Teknologi dapat menyebabkan ketergantungan pada gadget, internet dan alat komunikasi lainnya. Teknologi dapat mempermudah akses pada pornografi, dan akses pada kebutuhan yang bersifat konsumtif seperti belanja dan game online. Perkembangan ini dapat mempengaruhi pada menurunnya rasa cinta terhadap tanah air. Oleh karena itu sebaiknya dilakukan sosialisasi nilai-nilai bela Negara sebagai wujud rasa cinta tanah air pada masyarakat sekitar Pulau Untung Jawa. Rasa cinta tanah air dapat diwujudkan dengan berbagai kegiatan yang dilakukan seorang warga Negara dalam kegiatan sehari-hari. Rasa cinta tanah air ditunjukkan dengan menjaga tanah dan pekarangan serta seluruh ruang wilayah Indonesia, bangga sebagai bangsa Indonesia dan generasi muda, menjaga nama baik bangsa Indonesia, memberikan kontribusi pada kemajuan bangsa dan negara, dan mencintai produk dalam negeri, budaya dan kesenian bangsa.

Bela Negara adalah konsep yang disusun dengan perundang-undangan dan pimpinan Negara tentang patriotism seseorang, atau kelompok dalam menjaga stabilitas keamanan Negara sebagai wujud rasa cinta tanah air. Setiap warga Negara berhak dan wajib untuk melakukan upaya bela Negara. UUD 1945 Pasal 27 ayat (3) menyebutkan: "bahwa setiap warga Negara berhak dan wajib ikut serta dalam upaya bela Negara. UUD 1945 Pasal 30 Ayat (1) dan (2): "bahwa setiap warga Negara berhak dan wajib ikut serta dalam usaha pertahanan dan keamanan Negara, dan usaha pertahanan dan keamanan Negara dilaksanakan melalui sistem pertahanan dan keamanan rakyat semesta oleh TNI dan kepolisian sebagai komponen utama, rakyat sebagai komponen pendukung."

Didalam UU N0.3 Tahun 2002 dijelaskan bahwa upaya bela negara adalah sikap dan perilaku warga negara yang dijiwai oleh kecintaannya kepada Negara Kesatuan Republik Indonesia yang berdasarkan Pancasila dan UUD 1945 dalam menjamin kelangsungan hidup bangsa dan Negara.

Bela Negara adalah wujud rasa cinta tanah air dengan menjaga keamanan dengan ikut serta melakukan pertahanan keamanan 
dari berbagai ancaman yang dianggap mampu menggoyahkan Negara. Namun, menurut Sunarso (2008) bela negara memiliki urgensi pada empat hal esensial yang harus dibela yaitu kemerdekaan Negara dan kedaulatan negara Republik Indonesia, kesatuan dan persatuan bangsa, keutuhan wilayah dan yuridiksi nasional, dan nilainilai Pancasila dan UUD 1945. Sehingga, bela Negara adalah implementasi pembelaan Negara melalui fisik dan non fisik.

Secara fisik, bela Negara dapat diartikan adalah wujud rasa cinta tanah air seorang warga Negara dengan menjaga kedaulatan Negara dengan cara fisik atau berperang dengan atau tanpa menggunakan senjata. Sedangkan melalui non fisik, bela Negara dapat diartikan sebagai wujud rasa cinta tanah air seorang warga Negara dengan kemampuan intelektual maupun akademis yang dimilikinya.

Sehingga dapat diartikan bahwa cinta tanah air adalah pondasi kuat dalam upaya menjalankan hak dan kewajiban seorang warga Negara untuk bela Negara. Oleh karena itu, sebaiknya dilakukan sosialisasi mengenai pentingnya rasa cinta tanah air dalam mempersiapkan generasi milenial dengan potensi profesi dan kewirausahaan di Pulau Untung Jawa.

\section{METODE}

Metode yang dilakukan dalam kegiatan pengabdian kepada masyarakat ini yaitu berupa penyuluhan kepada remaja milenial tentang pentingnya rasa cinta tanah air dalam mempersiapkan generasi milenial dengan potensi profesi dan kewirausahaan di Pulau Untung Jawa.

Teknik pengambilan data selama pengabdian masyarakat dilakukan dengan melakukan observasi, wawancara, dan melakukan pre test- post test. Hasil wawancara menunjukkan bahwa potensi Pulau Untung Jawa sebagai salah satu obyek wisata pilihan wisatawan domestic dan mancanegara belum dimaksimalkan. Hal tersebut dapat terlihat dengan obyek wisata sekitar pulau belum memiliki manajemen yang kuat, dan jumlah usaha yang dikelola oleh masyarakat lokal masih belum maksimal.

Oleh karena itu, rencana pelaksanaan kegiatan pengabdian kepada masyarakat akan dilakukan dengan memberikan workshop penanaman nilai-nilai cinta tanah air melalui potensi profesi. Kegiatan ini mengundang warga sekitar sejumlah 50 orang. Tempat pengabdian dilakukan di Pulau Untung Jawa Kepulauan Seribu Jakarta. Pengabdian kepada Masyarakat dilakukan pada bulan Desember 2019 sampai dengan Januari 2020. Sosialisasi dilakukan oleh tim pengabdian kepada 
masyarakat yaitu dosen beserta mahasiswa di Universitas Pamulang.

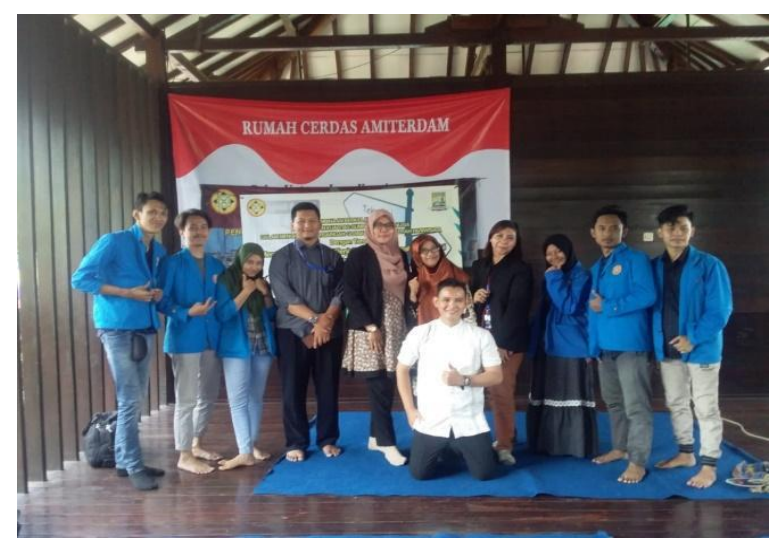

Sumber: Dokumentasi Penulis, 2019

\section{Gambar 1}

Panitia Pengabdian kepada Masyarakat

Kegiatan pengabdian masyarakat ini diharapkan dapat memberikan tambahan wawasan dan keterampilan peserta dalam upaya mewujudkan rasa cinta tanah air dengan potensi profesi dan wirausaha di tengah-tengah era revolusi industri yang semakin berkembang. Sosialisasi dilakukan agar peserta mampu menyampaikan dan potensi profesi dan wirausaha.

Selain kegiatan sosialisasi, Pengabdian kepada Masyarakat direncanakan dapat memberikan demonstrasi pembuatan kerajinan tangan dan memberikan kesempatan peserta untuk mempraktekkan pembuatan kerajinan tangan sehingga dapat terlihat secara langsung perkembangan kompetensi peserta dalam kemampuan berwirausaha. Pelatihan ini dilakukan oleh trainer yaitu dosen Universitas Pamulang.
Sosialisasi nilai-nilai profesi dan wirausaha dilakukan sebagai cara untuk memberikan motivasi kepada masyarakat mengenai manfaat kreativitas untuk meningkatkan perekonomian, serta pemanfaatan barang bekas untuk pembuatan kerajinan tangan sebagai alternatif dalam berwirausaha. Sosialisasi dilakukan dengan harapan bahwa masyarakat dapat menerima proses pembuatan kerajinan tangan sebagai hal yang sederhana dan murah namun bermanfaat dan dapat menghasilkan keuntungan sehingga menumbuhkan jiwa kewirausahaan dalam diri masyarakat pulau untung jawa.

Sosialisasi dilanjutkan dengan penanaman nilai-nilai bela Negara melalui penanaman nilai-nilai cinta tanah air. Sosialisasi ini dilakukan untuk dapat memberikan motivasi dan pemahaman kepada masyarakat sekitar mengenai nilainilai bela Negara dengan melalui penanaman nilai-nilai cinta tanah air dan mengamalkannya dalam kehidupan seharihari.

Pada tahap akhir dilakukan demonstrasi. Demonstrasi dilakukan dengan cara sederhana yaitu mengadakan pertemuan di kelurahan desa Untung Jawa dengan mengundang warga dan mempraktekkan pembuatan kerajinan tangan. Setelah demonstrasi selesai dilakukan, praktek pembuatan kerajinan dilakukan oleh peserta 
Pengabdian kepada Masyarakat. Praktek pembuatan kerajinan tangan oleh warga untuk melihat apakah pembuatan kerajinan oleh warga sudah sesuai dengan urutan pembuatan dan selesai sesuai target. Peserta kegiatan dibagi menjadi beberapa kelompok dan setiap kelompok diharapkan dapat menyelesaikan satu buah kerajinan tangan. Partisipasi masyarakat sangat terlihat dari banyaknya peserta yang hadir.

Secara rinci berikut ini susunan kegiatan Pengabdian kepada Masyarakat:

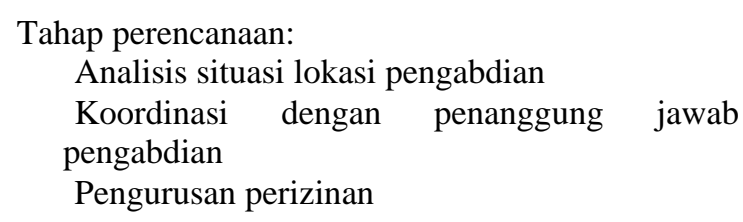

Tahap pelaksanaan:

Memberikan sosialisasi nilai-nilai cinta tanah air

Memberikan sosialisasi nilai-nilai profesi dan kewirausahaan

Diskusi mengenai potensi profesi dan kewirausahaan di kelurahan Pulau Untung Jawa

Tahap pelaporan:

Penyusunan laporan

Penyusunan luaran kegiatan

Sumber: Dokumentasi Penulis, 2019

Gambar 2. Tahapan Pelaksanaan Pengabdian kepada Masyarakat

\section{HASIL DAN PEMBAHASAN}

Pelaku usaha adalah seseorang yang berperan untuk memulai dan menjalankan kegiatan usaha dengan kreativitas dan inovasi. Sehingga seorang pelaku usaha adalah seseorang dengan daya kreativitas dan inovasi untuk mendirikan dan mengelola usaha untuk mengelola, memanfaatkan, menghadapi hambatan dan tantangan dalam pelaksanaannya. Pelaku usaha memiliki kemampuan yang baik dalam upaya mengatasi masalah dan memanfaatkan peluang yang ada di masyarakat. Pelaku usaha memanfaatkan kreativitas dan inovasi yang dimiliki untuk menghasilkan produk atau jasa yang memiliki manfaat untuk hajat hidup orang banyak. Selain itu, pemilik usaha harus mampu membaca peluang apa, dimana, kapan, siapa yang menjalankan dan bagaimana usaha tersebut dilakukan. Peluang bisnis dapat muncul dari berbagai inspirasi, ide, atau kesempatan untuk dapat digunakan sebagai dasar dimulainya sebuah kegiatan yang memiliki manfaat bagi orang lain.

Selain itu, Pulau Untung Jawa adalah tujuan wisata bagi berbagai wisatawan lokal dan mancanegara sehingga memberikan peluang usaha bagi masyarakat sekitar Pulau Untung Jawa. Namun hal ini belum dimanfaatkan dengan baik. Hal tersebut ditunjukkan dengan masih terbatasnya wirausahawan yang berasal dari Pulau 
Untung Jawa. Oleh karena itu sebaiknya dilakukan sosialisasi maupun pelatihan untuk meningkatkan kemampuan wirausaha masyarakat sekitar pulau Untung Jawa. Berdasarkan pengamatan yang dilakukan sebelumnya, Pulau Untung Jawa adalah salah satu destinasi yang menjadi pilihan utama wisatawan lokal dan mancanegara sehingga dapat memberikan dampak positif dan negatif dari kunjungan para wisatawan. Hal ini sebaiknya diantisipasi dengan memberikan sosialisasi nilai-nilai rasa cinta tanah air melalui potensi profesi dan kewirausahaan.

Berangkat dari definisinya, cinta tanah air adalah perasaan cinta seorang warga Negara diwujudkan dengan bagaimana seseorang tersebut menjaga tanah dan pekarangan serta seluruh ruang wilayah Indonesia, memiliki kebanggan bahwa dirinya adalah bagian dari bangsa Indonesia dan generasi muda, menjaga nama baik bangsa Indonesia, berkontribusi positif pada kemajuan bangsa dan negara, dan mencintai produk buatan dalam negeri, budaya dan kesenian bangsa.

Penanaman rasa cinta tanah air diharapkan menjadi pondasi awal bagi peserta pengabdian kepada masyarakat untuk menjalani kehidupannya di Pulau Untung Jawa di tengah-tengah keberagaman budaya yang hadir dari wisatawan baik domestic maupun mancanegara. Rasa cinta tanah air dapat diwujudkan dengan sikap sebagai berikut menjaga Pulau Untung Jawa dari sampah-sampah yang dibuang sembarangan, bangga menjadi masyarakat kelurahan Pulau Untung Jawa yang memiliki kearifan lokal, budaya dan adat istiadatnya, menjaga nama baik bangsa dengan menjaga nilai-nilai dan norma yang terkandung dalam kehidupan bermasyarakat, berkontribusi pada kemajuan bangsa dan Negara melalui keahlian dan kemampuan masing-masing, dan mencintai produk-produk buatan dalam negeri, kebudayaan serta kesenian khususnya milik masyarakat pulau Untung Jawa.

Pulau Untung Jawa memberikan peluang usaha yang besar bagi masyarakat sekitar. Namun hal ini sekaligus menjadi tantangan bagi masyarakat karena dengan semakin banyaknya wisatawan domestic dan mancanegara yang hadir dapat memberikan berbagai macam pengaruh baik dalam bentuk positif maupun negatif dalam kehidupan sehari-hari. Oleh karena itu, sebaiknya dapat dihadapi dengan adanya rasa cinta tanah air yang kuat pada diri masyarakat sehingga tidak dengan mudah terpengaruh dengan kehadiran kebiasaan dan budaya luar yang berpengaruh buruk bagi terjaganya nilai-nilai yang terkandung dalam kehidupan bermasyarakat Pulau Untung Jawa.

Pulau Untung Jawa adalah tujuan wisata bagi berbagai wisatawan lokal dan mancanegara sehingga memberikan peluang 
usaha bagi masyarakat sekitar. Berdasarkan observasi yang dilakukan ke lokasi Pengabdian kepada Masyarakat, dapat diketahui bahwa masyarakat sekitar pulau Untung Jawa masih minim yang memanfaatkan peluang usaha tersebut. Hal tersebut ditunjukkan dengan masih terbatasnya wirausahawan yang berasal dari Pulau Untung Jawa. Untuk menghadapi permasalahan tersebut, dilakukan sosialisasi untuk meningkatkan kemampuan wirausaha masyarakat sekitar pulau Untung Jawa.

Pengabdian kepada masyarakat dilakukan dengan sosialisasi nilai-nilai cinta tanah air dengan potensi profesi dan wirausaha. Sosialisasi disempurnakan dengan pelatihan pembuatan kerajinan tangan melalui demonstrasi pembuatan dan praktik pembuatan kerajinan tangan.

Sosialisasi ini dilakukan dengan tujuan untuk dapat meningkatkan minat wirausaha masyarakat sekitar sehingga mampu menyadari peluang besar yang dapat dihasilkan dari wirausaha di sekitar tempat wisata seperti: usaha kuliner, penginapan, jasa foto sesi di pantai, oleh-oleh khas pulau Untung Jawa, dan lain sebagainya.

Pulau Untung Jawa adalah tujuan wisata bagi berbagai wisatawan lokal dan mancanegara sehingga dapat memberikan dampak positif dan negatif dari kunjungan para wisatawan. Sebagaimana penelitian yang dilakukan oleh Nursyifa (2018) kawasan wisata dapat memberikan dampak positif maupun negatif bagi masyarakat sekitar, sehingga masyarakat dapat berupaya menyesuaikan diri keberadaan objek wisata agar memberikan manfaat positif sesuai dengan nilai-nilai budaya bangsa.

Dampak negatif keberadaan budaya yang tidak sesuai dapat diantisipasi dengan memberikan sosialisasi nilai-nilai rasa cinta tanah air. Wisatawan mancanegara dapat memberikan pengalaman baru bagi masyarakat sekitar dengan memiliki budaya dan kebiasaan berbeda dengan penduduk lokal. Oleh karena itu, rasa cinta tanah air dapat diperkuat untuk menangkal dampak yang tidak diinginkan. Rasa cinta tanah air adalah perasaan seorang warga Negara yang ditunjukkan dengan menjaga tanah dan pekarangan serta seluruh ruang wilayah Indonesia, memiliki perasaan bangga sebagai bagian dari bangsa Indonesia dan generasi muda, mewujudkan tindakan dengan menjaga nama baik bangsa Indonesia, memberikan kontribusi pada kemajuan bangsa dan negara, dan mencintai produk dalam negeri, budaya dan kesenian bangsa. Kegiatan ini diharapkan dapat menjadi langkah yang berkelanjutan bagi peserta pengabdian kepada masyarakat untuk menjalani kehidupannya di Pulau Untung Jawa di tengah-tengah keberagaman budaya yang hadir dari wisatawan baik domestic maupun mancanegara. Rasa cinta tanah air 
dapat diwujudkan dengan sikap sebagai berikut:

1. Menjaga Pulau Untung Jawa dari sampah-sampah yang dibuang sembarangan;

2. Bangga menjadi masyarakat kelurahan Pulau Untung Jawa yang memiliki kearifan lokal, budaya dan adat istiadatnya;

3. Menjaga nama baik bangsa dengan menjaga nilai-nilai dan norma yang ada di masyarakat;

4. Berkontribusi pada kemajuan bangsa dan Negara melalui keahlian dan kemampuan masing-masing; dan

5. Mencintai produk-produk buatan dalam negeri, kebudayaan serta kesenian khususnya milik masyarakat pulau Untung Jawa.

Kegiatan pengabdian kepada masyarakat dilakukan dengan memberikan sosialisasi nilai-nilai cinta tanah air dengan potensi profesi dan wirausaha. Kegiatan ini dihadiri oleh warga sekitar sejumlah 50 orang. Sosialisasi diberikan dengan memberikan penanaman nilai-nilai cinta tanah air terhadap 50 orang peserta. Selain itu, pengabdian kepada masyarakat juga sebagai upaya untuk dapat meningkatkan rasa cinta tanah air dengan potensi profesi dan wirausaha. Oleh karena itu, pengabdian kepada masyarakat dilakukan juga dengan demonstrasi pembuatan kerajinan tangan untuk menambah keterampilan peserta. Dalam hal ini dosen berperan sebagai trainer (pelatih) pembuatan kerajinan tangan. Demonstrasi dilakukan dengan memberikan contoh pembuatan kerajinan tangan di hadapan peserta. Pengabdian kepada masyarakat dilanjutkan dengan praktik pembuatan kerajinan tangan oleh peserta.

Kegiatan ini memberikan dampak positif pada rasa cinta tanah air di diri peserta Pengabdian kepada Masyarakat. Hal ini dapat dilihat dari hasil peningkatan nilainilai cinta tanah air yang diwujudkan dari peningkatan rata-rata nilai dari pre-test jika dibandingkan dengan post-test. Berdasarkan data pre-test diketahui didapatkan bahwa nilai rata-rata adalah 65,2 dengan nilai terendah 51,3 dan nilai tertinggi 74,6. Kemudian, setelah dilakukan pengabdian kepada masyarakat, diketahui nilai rata-rata post-test meningkat menjadi 78,1 dengan nilai terendah 65,4 dan nilai tertinggi 84,2.

Pengabdian masyarakat yang dilakukan dapat meningkatkan rasa cinta tanah air generasi muda. Pengabdian masyarakat tentang penanaman cinta tanah air pernah dilakukan oleh Megawati (2019) hasil pengabdianya memberikan pemahaman secara teoritis maupun aplikatif terhadap sikap cinta tanah air di lingkungan sebagai satu antisipasi menghadapi era disrupsi 4.0 yang tidak dapat dihindari. 
Dalam pengabdian kepada masyarakat ini berupaya untuk meningkatkan keterampilan generasi milenial melalui pelatihan pembuatan kerajinan tangan melalui demonstrasi dan praktek pembuatan kerajinan. Berdasarkan hasil pelatihan melalui demonstrasi dan praktek, dapat diketahui keterampilan peserta meningkat. Peningkatan keterampilan peserta dinilai dari proses pembuatan kerajinan tangan sesuai dengan tahapan yang didemonstrasikan, dan dari kreativitas serta inovasi masing-masing peserta dalam memperindah hasil karya.

Berdasarkan hasil penilaian, 47 peserta mampu mengikuti proses pembuatan kerajinan tangan hingga selesai sesuai dengan tahapan yang telah didemonstrasikan. Hal ini menunjukkan bahwa mayoritas peserta telah dapat mengikuti pelatihan sesuai dengan prosedur yang telah ditentukan. Peserta yang mengikuti proses pelatihan sesuai dengan prosedur yang telah ditentukan adalah wujud keberhasilan pengabdian kepada masyarakat dalam meningkatkan keterampilan peserta.

Peserta pelatihan diharapkan dapat menjadi pioneer bagi masyarakat kelurahan Pulau Untung Jawa dalam memanfaatkan peluang usaha di Pulau Untung Jawa. Peserta diharapkan dapat memberikan informasi kepada masyarakat lain untuk semakin mengembangkan keterampilan demi mendukung potensi profesi dan wirausaha di
Pulau Untung Jawa. Pelatihan ini juga dapat memberikan alternatif usaha bagi peserta.

Namun, disamping itu, masih terdapat 3 orang peserta belum dapat mengikuti pelatihan secara maksimal. Hal ini ditunjukkan dengan adanya penyelesaian proses pembuatan kerajinan belum tepat sesuai dengan waktu yang telah diberikan oleh pelatih (trainer). Hal ini menjadi bahan evaluasi bagi pelatih untuk pengabdian kepada masyarakat berikutnya apakah perlu diberikan waktu tambahan pada saat pelatihan atau jumlah pelatih yang harus ditambahkan sehingga mempermudah pemahaman peserta dengan pendampingan pelatih yang bertambah banyak.

\section{KESIMPULAN}

Kegiatan pengabdian kepada masyarakat dilakukan dengan memberikan sosialisasi nilai-nilai cinta tanah air melalui potensi profesi dan wirausaha. Kegiatan ini dihadiri oleh warga sekitar sejumlah 50 orang. Sosialisasi diberikan dengan memberikan penanaman nilai-nilai cinta tanah air pada diri peserta. Selain itu, pengabdian kepada masyarakat juga dilakukan untuk meningkatkan rasa cinta tanah air dengan potensi profesi dan wirausaha. Oleh karena itu, pengabdian kepada masyarakat dilakukan juga dengan demonstrasi pembuatan kerajinan tangan untuk menambah keterampilan peserta. 
Dalam hal ini dosen berperan sebagai trainer (pelatih) pembuatan kerajinan tangan. Demonstrasi dilakukan dengan memberikan contoh pembuatan kerajinan tangan di hadapan peserta. Pengabdian kepada masyarakat dilanjutkan dengan praktik pembuatan kerajinan tangan oleh peserta.

Kegiatan ini memberikan dampak positif pada diri peserta. Hal ini dapat dilihat dari hasil peningkatan nilai-nilai cinta tanah air yang diwujudkan dari peningkatan ratarata nilai dari pre-test dengan post-test. Berdasarkan data pre-test diketahui nilai rata-rata adalah 65,2 dengan nilai terendah 51,3 dan nilai tertinggi 74,6. Kemudian, setelah dilakukan pengabdian kepada masyarakat, diketahui nilai rata-rata post-test meningkat menjadi 78,1 dengan nilai terendah 70,0 dan nilai tertinggi 84,2.

Berdasarkan hasil penilaian tersebut, dapat diketahui bahwa nilai-nilai cinta tanah air dalam diri peserta meningkat. Namun, diperlukan tindak lanjut kegiatan untuk menilai apakah peserta telah mengamalkan sikap-sikap yang menunjukkan rasa cinta tanah air dalam kehidupannya sehari-hari.

Keterampilan peserta meningkat dengan adanya pelatihan pembuatan kerajinan tangan melalui demonstrasi dan praktek pembuatan kerajinan. Berdasarkan hasil pelatihan melalui demonstrasi dan praktek, dapat diketahui keterampilan peserta meningkat. Peningkatan keterampilan peserta dinilai dari proses pembuatan kerajinan tangan sesuai dengan tahapan yang didemonstrasikan, dan dari kreativitas serta inovasi masing-masing peserta dalam memperindah hasil karya. Keterampilan yang didapatkan melalui pelatihan dapat dimanfaatkan untuk menjadi profesi dan kesempatan untuk berwirausaha.

Berdasarkan hasil penilaian, 47 peserta mampu mengikuti proses pembuatan kerajinan tangan hingga selesai sesuai dengan tahapan yang telah didemonstrasikan. Namun masih terdapat 3 orang peserta belum menyelesaikan proses pembuatan kerajinan tepat waktu sesuai dengan waktu yang telah diberikan oleh pelatih (trainer). Hal ini menjadi bahan evaluasi bagi pelatih untuk pengabdian kepada masyarakat berikutnya apakah perlu diberikan waktu tambahan pada saat pelatihan atau jumlah pelatih yang harus ditambahkan sehingga mempermudah pemahaman peserta dengan pendampingan pelatih yang bertambah banyak. Hal ini menjadi bahan masukan bagi pengabdi berikutnya untuk dapat mengembangkan teknik pelatihan sehingga lebih mudah diterima peserta. 


\section{REFERENSI}

Andrew J. DuBrin. 2008. Essentials of Management. South Western Educational Publishing

Kusnandar. 2007. Guru Profesional. Jakarta: PT Raja Grafindo.

Megawati, E., \& Megawanti, P. (2019). Edukasi Gerakan Sekolah dan Penanaman Cinta Tanah Air dalam Menghadapi Era Revolusi Disrupsi 4.0 Pada Anggota Yayasan Bina Utama Melati. Jurnal Pengabdian kepada Masyarakat, 25(1), 13-19.
Nursyifa, A. (2018). Kajian Cultural Lag dalam Kehidupan Masyarakat Perkampungan Budaya Betawi Setu Babakan Pada Era Globalisasi. Jurnal Pendidikan Kewarganegaraan, 5(1), 124.

Sunarso, et., al. (2008). Pendidikan Kewarganegaraan untuk Perguruan Tinggi. Yogyakarta: UNY Press.

Zimmerer, Thomas W \& Scarborough, Norman M.(2008). Kewirausahaan dan Manajemen Usaha Kecil (Edisi 5). Jakarta: Salemba Empat. 